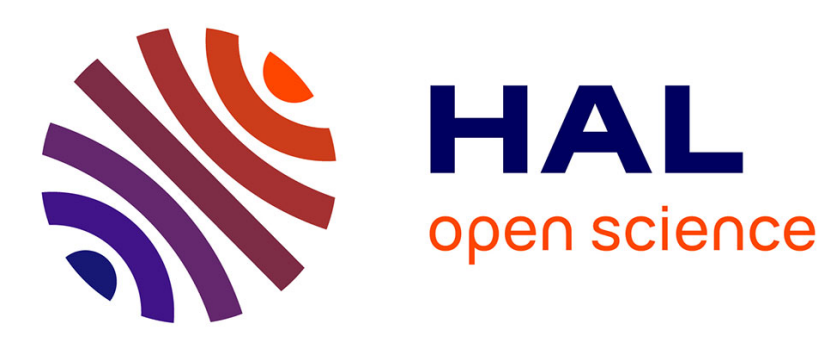

\title{
Where is the North China-South China block boundary in eastern China?
}

\author{
Michel Faure, Wei Lin, Nicole Le Breton
}

\section{To cite this version:}

Michel Faure, Wei Lin, Nicole Le Breton. Where is the North China-South China block boundary in eastern China?. Geology, 2001, 29, pp.119-122. 10.1130/0091-7613(2001)0292.0.CO;2 . hal00078015

\section{HAL Id: hal-00078015 \\ https://hal-insu.archives-ouvertes.fr/hal-00078015}

Submitted on 2 Jun 2006

HAL is a multi-disciplinary open access archive for the deposit and dissemination of scientific research documents, whether they are published or not. The documents may come from teaching and research institutions in France or abroad, or from public or private research centers.
L'archive ouverte pluridisciplinaire HAL, est destinée au dépôt et à la diffusion de documents scientifiques de niveau recherche, publiés ou non, émanant des établissements d'enseignement et de recherche français ou étrangers, des laboratoires publics ou privés. 


\title{
Where is the North China-South China block boundary in eastem China?
}

\author{
Michel Faure, Wei lin, and Nicole Le Breton \\ Institut des Sciences de la Terre d'Orléans, Bâtiment Géosciences, Université \\ d'Orléans, 45067 O réans Cedex 2, France
}

\begin{abstract}
The Qinling-Dabieshan belt results from the collision of the North China and South China blocks. The eastem extension of the belt (the Sulu area) consists of several stacked units: from top to bottom, these are (1) a weakly metamomhosed slate-sandstone unit of Neoproterozoic-Paleozoic age, (2) a gneiss-quartzite unit metamorphosed under highpressure $(P)$ conditions, (3) a marble-amphibolite unit, (4) an ultrahigh-P unit that was very deeply subducted and then exhumed, and (5) a migmatitic dome resulting from the melting of ultrahigh-P rocks. All these units underwent the same deformation, which was characterized by a top-to-the-northwest extensional ductile shearing, during their exhumation. Granulite facies restites in the migmatite are not significantly different from granulitized eclogites derived from the ultrahigh-P rocks. The migmatite exhibits the same structural and petrologic evolution as that determined for the other units. The resemblance of petrologic and structural features and the lack of ocean-basin rock shows that the boundary between the North China block and South China block must be placed north of the Sulu area.
\end{abstract}

Keywords: suture zone, exhumation, granulite facies, detachment fault, China.

\section{INTRODUCTION}

In China, the east-trending Qinling-Dabieshan belt is a wide orogen formed by the collision of the North China and South China blocks (Mattauer et al., 1985, 1991 ; Okay and Sengör, 1992 ; Cong, 1996 ). The Dabieshan, on the east of the chain, is famous for its ultrahigh-pressure $(P)$ metamorphism. The occurrence of coesite eclogite and ultrahigh-P minerals in gneiss demonstrates that the continental crust of the South China block was subducted to more than $100 \mathrm{~km}$ depth and afterward exhumed. To the east of the Dabieshan, the orogen is offset by the Tan-Lu fault. Ultrahigh-P rocks crop out $500 \mathrm{~km}$ northward in the northem Jiangsu and eastem Shandong Provinces, or Sulu area. There, in spite of several tens of papers dealing with metamorphism of the ultrahigh-P rocks (e.g., Cong, 1996; Banno et al., 2000; Yao et al., 2000), structural data a re rare (Wa llis et a l., 1997, 1999), and thus a general tectonic framework is still lacking. It is, however, an essential prerequisite in order to propose any geodynamic scenario. 
This paper presents a structural map and crustal-scale cross sections of the Sulu area based on firsthand data. The structural analyses together with a new discovery of high-P granulite in the so-called North China Precambrian basement of the north Jiaodong Peninsula allow us to argue that the boundary between the North and South China blocks must be to the north of the Sulu area.

\section{TECTONIC MAPOFTHEJIAODONG PENINSULA}

Our field survey in the Jiaodong Peninsula allows us to recognize a stack of tectonic-metamorphic units unconformably covered by Upper JurassicCretaceous volcanic and sedimentary rocks or intruded by Cretaceous plutons. The general structure of the peninsula is somewhat complicated by northeast-southwest-trending nomal and left-lateral brittle faults (Shandong Bureau of Geology and Mineral Resources, 1991 ). Among these, the WulianYantai fault (Fig. 1) separates the so utheastem Sulu area, where ultrahigh-P rocks a re widely exposed, from the northwestem Sulu area, where gneisses, marbles, amphibolites, and migmatites are conspicuous. For this reason, the Wulian-Yantai fault has been considered as the suture zone between the South and North China blocks (Okay and Sengör, 1992; Yin and Nie, 1993; 1994, Cong, 1996; Gilder et al., 1999; Zhai et al., 2000). Prior to the Mesozoic, the Jiaodong Peninsula underwent deep-seated tectonics associated with the stacking of metamorphic allochthons overprinted by a migmatitic dome. From to $p$ to bottom, the following units a re distinguished (Fig. 1).

\section{Neoproterozoic (Sinian) to Paleozoic (?) Slate-Sandstone Unit}

These weakly to unmetamorphosed rocks, called the Penglai Group, are Neoproterozoic (Sinian) or Paleozoic age (Cong, 1996) and crop out in the northem part of the Sulu area. The slate-sandstone unit is mapped as unconformably overlying the metamorphic rocks (Shandong Bureau of Geology and Mineral Resources, 1991 ). However, striations on bedding surfaces and recumbent folds argue for a north-directed detachment fault between the two units (Fig. 2).

\section{High-Pressure Gneiss-Quartite Unit}

A gneiss-quartzite unit is found a long the sea coast near the Lianyungang City (Fig. 1). The unit is also recognized by drilling below the Holocene sediments. High-P rocks with glaucophane, jadeite, kyanite, and phengite occur sporadically (Cong, 1996). The boundary between the ultrahigh- and high-P units, called the Haizhou-Siyang fault, is only known through geophysic al data (Cong, 1996). 


\section{Marble-Amphibolite Unit}

Although designated as Wulian or Fenzishan Groups in the north and south sides of the Mesozoic basin, respectively (Shandon Bureau of Geology and Mineral Resources, 1991 ), identical marbles, mafic intrusions, and a few gneisses and metapelites form the marble-amphibolite unit. The presence of a tectonic contact between this unit and the slate-sandstone unit is supported by a metamorphic gap and by the lack of the gneiss-quartzite unit in the northeastem part of Jiaodong Peninsula. Eclogite facies rocks are not reported in this unit, thus we consider that it was never subjected to the ultrahigh-P metamorphism. The marble-amphibolite unit overlies the ultrahigh$\mathrm{P}$ unit with a 1-2-km-thick mylonitic contact (ig. 2B).

\section{Ultrahigh-Pressure Unit}

The ultrahigh-P unit consists of mafic rocks, quartzite, gneiss, and marble. Coesite eclogites attest to severe metamorphic conditions (Wang et al., 1993 ; Zhang et al., 1995 ; Cong, 1996 ). The occurrence of jadeite orthogneiss (Hirajima et al., 1993) demonstrates that all the continental rocks were deeply subducted. Meter- to kilometer-size gamet lherzolite and pyroxenite bodies record the ultrahigh-P event (Zhang et al., 1994). However, these ultramafic bodies do not represent deeply subducted ocean-basin mantle. If not all, then at least some of the ultramafic rocks a re crustal-hosted peridotites that correspond to cumulates associated with intracontinental basalts emplaced within the south China continental crust in Proterozoic time. No mafic magmatic rocks or marine sedimentary rocks have been identified. The lack of oceanic crust and mantle allows us to conclude that an oceanic suture is not represented in the Sulu a rea.

\section{Foliated Migmatite Unit}

In the northem part of the Jiaodong Peninsula, north of the Mesozoic basin, foliated migmatite crops out. Typical migmatitic features such as nebulitic structures with contorted leuc osome layers and K-feldspar porphyroblasts a re locally well preserved, but the most common rock is a foliated diatexite with conspicuous planar and linear fabrics. The Al-Si-rich gneisses could have easily been partially melted to give rise to the leucosome, whereas the abundant amphibolite masses represent the unmelted Fe-Mg-rich restites. This migmatite is seen as the basement of the North China block, but relicts of high-P rocks suggest that it derives from the melting of the ultrahigh-P unit.

\section{STRUCTURALANALYSIS AND KINEMATICS}

The bulk structure of the Jiaodong Peninsula consists of a succession of southwest-northeast-trending anticlines and synclines. The antiform north of 
Laiyang is a migmatitic dome surrounded by the marble-amphibolite and slate-sandstone units (Fig. 2A). The central J iaodong sync line is filled by Upper J urassic-Cretaceous deposits. Southwest of Qingdao, the ultrahigh-P unit occupies the core of an antiform (Fig. 2B). Ultrahigh-P rocks constitute the deepest unit exposed. By comparison with Dabieshan (Faure et al., 1999), we assume that the ultrahigh-P unit is underla in by non ultrahigh-P gneisses. This is supported by seismic reflection data (Yang, 2000).

In every unit, a stretching lineation that trends $\mathrm{N} 130^{\circ}-\mathrm{N} 160^{\circ} \mathrm{E}$ is the dominant feature (Fig. 1). Close to the contact between the marble-amphibolite unit and the slate-sandstone unit, the dikes are deformed into sigmoidal boudins with top-to-the-northwest shearing. The mineral lineation and top-to-thenorthwest kinematics are also common in the ultrahigh-P unit. In the upper part of the ultrahigh-P unit, orthogneiss and amphibolites bodies are progressively changed into augen mylonite or ultramylonite. Top-to-thenorthwest kinematics are also found in the gneiss-quartzite high-P unit. However, rare top-to-the-southeast senses of shear are also developed near Lianyungang (Fig. 1).

In the migmatite, recrysta lization textures of qua rtz and K-feldspar a ggregates indicate that the foliation and lineation were acquired in a postsolidus stage. East and south of Weihai, mylonitic fabrics overpint the migmatite. There, the migmatitic foliation is changed into a flat-lying banded gneiss with northwesttrending stretching lineation and intrafolial folds. This top-to-the-northwest ductile shear zone is coeval with an amphibolite facies metamorphism that overprints the ultrahigh-P event and migmatization. The shear zone is interpreted here as a detachment fault along which the exhumation of the ultra high-P rocks occurred.

A second ductile deformation, restricted to the northem area, refolds the foliation and lineation. The orientation and overtuming of the postfoliation folds exhibit a divergent dome pattem; i.e., on the west, north, southeast, and south sides of the dome, the folds are overtumed to the west, northeast, southeast, and south, respectively. The dome and recumbent folds are covered by undeformed J urassic rocks.

\section{NEW PEIROLOGIC INSGHIS}

High-P granulites reported from Laiyang a re considered as Precambrian rocks of the North China block (Zhai et al., 2000). New occurrences have been discovered in a remote location with respect to the Wulian-Yantai fault (Fig. 1). These rocks form decimeter- to meter-scale gamet amphibolite blocks enclosed within foliated migmatite. Granulite facies symplectites of clinopyroxene + plagioclase + hypersthene are seen to have developed at the expense of the gamet + clinopyroxene + quartz assemblage (Fig. 3). In a 
late stage of amphibolitization, brown amphibole + plagioclase overprinted the symplectite. Gamets are compositionally zoned with an increase in $\mathrm{Mg}$ and decrease in Fe contents from core to rim. The symplectite consists of diopside (0.4-0.8 wt\% $\left.\mathrm{Na}_{2} \mathrm{O}\right)$ and andesine $\left(\mathrm{An}_{28-48}\right)$. Such a high $\mathrm{Na}$ content is explained by a breakdown reaction of a gamet $+\mathrm{Na}$ rich clinopyroxene + quartz assemblage. Thus, the retrograde metamorphism of eclogite appears to be the most likely process to produce this granulitic symplectite. Ultrahigh-P minerals have not been yet observed, but rare radial fractures around quartz inclusions in gamet might indicate that the inclusions are coesite pseudomorphs.

Several pressure-temperature paths have been constructed (Zhang et al., 1995; Yao et al., 2000; Fig. 4). In the Donghai area, the ultrahigh-P unit was never migmatized, and eclogite was retrograded into amphibolite. Closer to the migmatite, in Taohang (Figs. 1 and 4), the pressure-temperature ( $\mathrm{P}-\mathrm{T})$ path approaches the granulite facies. In Weihai, ultrahigh-P eclogites enclosed in foliated migmatites show a granulitic overpint (Wang et al., 1993; Zhang et al., 1995 ; Zhai et al., 2000 ). The retrograde metamomhism of the Weihai eclogite intersects the P-Tarea defined for the migmatite (Enami et al., 1993). Therefore, from the available petrologic data, it is impossible to separate an ultra high-P unit retrograded into granulite facies to the east from a migmatite with granulite facies xenoliths to the west.

\section{DISC USSION AND CONCLUSIONS}

The geometry and kinematics of the deformation phases demonstrate that the north and south parts of the Jiaodong Peninsula shared the same tectonic evolution. In addition to the lack of oceanic-basin rocks in the J iaodong Peninsula, our work shows that the Wulian-Yantai fault cannot be the suture zone between the North and South China blocks. The contact between the ultrahigh-P and marble-amphibolite units is a flat-lying, top-tothe-northwest ductile shear zone formed duning a late stage of exhumation of the ultrahigh-P metamomhic rocks under amphibolite facies conditions. This boundary was reworked as the high-angle, brittle Wulian-Yantai fault in late Mesozoic time.

The metamorphic evolution of the Sulu area must be older than Late J urassic . This stratigraphic constraint complies well with the radiometric ages of ultrahigh-P metamorphic rocks in the 240-210 Ma range, which is considered to be the date of the pressure peak (Ames et al., 1993; Li et al., 1994 ). Moreover, as in the Dabieshan, $90-110 \mathrm{Ma}{ }^{40} \mathrm{Ar} /{ }^{39} \mathrm{Ar}$ ages on musc ovite, biotite, homblende, and K-feldspar confim the importance of a Late Cretaceous themal event in eastem China (e.g., Chen et al., 1992; L et al., 1994; Eide et al., 1994; Lin et al., 2000). However, a problem arises when dealing with the geochronology of the migmatite. Zrcons extracted from 
gneissic migmatite north of Laiyang give dates between 1.5 and $2 \mathrm{Ga}$ (Enami et al., 1993 ; Ishizaka et al., 1994). Recent Sm-Nd analyses have provided isochrons from 1.74 to $1.84 \mathrm{Ga}$ (hai et al., 2000 ). It is acknowledged that these Paleoproterozoic dates represent the protolith age, but more surprisingly, these isotopic systems do not record any evidence of the Mesozoic events.

The geology of the Sulu area is quite similar to that of the Dabieshan (e.g., Hacker et al., 1995, 2000; Faure et al., 1999 ). In both areas, the ultrahigh-P metamorphism is overpinted by a migmatitic dome, and the main ductile deformation is a top-to-the-northwest shearing coeval with a mphibolite facies metamorphism. Amphibolite, gabbro, and marine sedimentary rocks cropping out in the northem Dabieshan area are interpreted as the trace of the suture zone between the North and South China blocks. In the Sulu area, the gneiss-quartzite unit, the ultrahigh-P unit, and migmatite dome are correlated with the corresponding units of the Dabieshan, but the marbleamphibolite unit has no equivalent in the Dabieshan. The crustal-scale cross section (Fig. 5) shows that the stack of allochthonous units belongs to the South China block.

Our correlation pattem raises the question of the location of the boundary between the North and South China blocks east of the Tan-Lu fault. Because the boundary cannot be located in the Jiaodong Peninsula, it has to be to the north. These new data have to be taken into account in any forthcoming exhumation models and paleogeodynamic reconstructions.

\section{REERENCES C IED}

Ames, L, Tilton, G., and Zhou, G., 1993, Timing of collision of the Sino-Korean and Yangtse cratons: U-Pb zirc on dating of coesite-bearing ec logites: Geology, 21, 239-242.

Banno, S., Enami, M., Hirajima, T., Ishiwata ri, A., and Wang, Q., 2000, Decompression pressure-temperature path of coesite eclogite to granulite from Weihai, eastem China: Lithos, 52, 97-108.

Chen, W., Ha mison, T.M., Heizler, M.T., Lu, R., Ma, B., and L, J., 1992, The cooling history of melange zone in north $\mathrm{J}$ iangsu-south Shandong region: Evidence for multiple diffusion doma in ${ }^{40} \mathrm{Ar} /{ }^{39} \mathrm{Ar}$ themal geochronology: Acta Petrologica Sinica, 8, 1-17.

Cong, B., 1996, Ultra high-pressure meta morphic rocks in the Dabieshan-Sulu region of China: Dordrecht, Netherlands, Kluwer Academic Publishers, 224 .

Eide, E.A., Mc Williams, M.O., and Liou, J .G., 1994, ${ }^{40} \mathrm{Ar} /{ }^{39} \mathrm{Ar}$ geochronology 
and exhumation of high-pressure to ultra high-pressure metamorphic rocks in east-central China: Geology, 22, 601-604.

Ena mi, M., Suzuki, K., Zhai, M., and Zheng, X., 1993, The chemic al Th-U-total Pb isochron a ges of J ia odong and J iaonan metamomhic rocks in the Shandong Peninsula, eastem China: The Island Arc, 2, 104-113.

Faure, M., Lin, W., Shu, L., Sun, Y., and Schärer, U., 1999, Tectonic s of the Dabieshan (eastem China) and possible exhumation mechanism of ultra-high pressure rocks: Terra Nova, 11, 251-258.

Gilder, S., Leloup, P.H., Courtillot, V., Chen, Y., Coe, S.R., Zhao, X., Xiao, W., Ha lim, N., Cogné, J.-P., and Zhu, R., 1999, Tectonic evolution of the TanchengLujiang (Tan-Lu) fault via Middle Triassic to early Cenozoic paleomagnetic data: J oumal of Geophysic al Research, 104, 15,365-15,390.

Hacker, B.R., Ratsbacher, L, Webb, L., and Dong, S., 1995, What brought them up? Exhumation of the Dabie Shan ultrahigh-pressure rocks: Geology, 23,, 743-746.

Hacker, B.R., Ratsba cher, L, Webb, L, Ireland, T., Calvert, A., Dong, S., Wenk, H.R., a nd Chateigner, D., 2000, Exhumation of the ultrahigh-pressure continental crust in east-central C hina: Late Tria ssic-Early J urassic extension: J oumal of G eophysic al Research,, 105, 13,339-13,364.

Hirajima, T., Wa llis, S., Zhai, M., and Ye, K., 1993, Ec logitized metagra nitoid from the Su-Lu ultrahigh pressure province, eastem China: J apan Aca demy Proceedings, 69, 249-254.

Ishiza ka, K., Hira jima, T., and Zheng, X.S., 1994, Rb-Sr dating for the J ia odong gneiss of the Sulu ultrahigh-pressure province eastem China: The Island Arc ,, 3, 232-241.

Li, S., Wang, Q., Chen, Y., Zhou, H., Zhang, Z, Lu, D., and Qiu, J., 1994, Excess argon in phengite of eclogite: Evidence for companing dating of eclogite by $\mathrm{Sm}-\mathrm{Nd}, \mathrm{Rb}-\mathrm{Sr}$, and ${ }^{40} \mathrm{Ar} /{ }^{39} \mathrm{Ar}$ isotope methods: Chemic al Geology, 112, 343350.

L, Z, 1994, Collision between the North and South China blocks: A crustaldetachment model for suturing in the region east of the Tanlu fault: Geology, $22,, 739-742$.

Lin, W., Faure, M., Monié, P., Schärer, U., Zhang, L, and Sun, Y., 2000, Tectonics of SE China, new insights from the Lushan massif (J iangxi Province): Tectonics, $19,852-871$. 
Mattauer, M., Matte, P., Mala vieille, J ., Tapponnier, P., Maluski, H., Xu, Z, Lu, Y., and Tang, Y., 1985, Tectonic s of the Q inling belt: Build-up and evolution of eastem Asia: Nature, 317, 496-500.

Mattauer, M., Matte, P., Maluski, H., Xu, Z, Zhang, Q., and Wang, Y., 1991, La limite Chine du Nord-Chine du Sud au Paléozoïque et au Trias: Nouvelles données structura les et radiométriques dans le massif du Dabieshan (chaîne des Q inling): Paris, Aca démie des Sciences Comptes Rendus, 312, 1227-1233.

Okay, A.I., and Sengör, A.M.C., 1992, Evidence for continental thrust-related exhumation of the ultra-high pressure rocks in China: Geology, 20, 411-414.

Shandong Bureau of Geology and Mineral Reso urces (SBG MR), . , 1991, Regional geology of Shandong province: Beijing, Geological Public ations, 639 p.

Wallis, S., Ishiwata n, A., Hirajima, T., Ye, K., Guo, J ., Naka mura, D., Kato, T., Zhai, M., Enami, M., Cong, B., and Banno, S., 1997, Occurrence and field relationships of ultra high-pressure meta gra nito id and coesite eclogite in the Sulu terra ne, eastem China: Geologic al Society of Lond on J oumal, 154, 45-54.

Wallis, S., Enami, M., and Banno, S., 1999, The Sulu UHP terrane: A review of the petrology and structural geology: Intemational Geology Review, 41, 906-920.

Wang, Q., Ishiwatari, A., Zha o, Z, Hirajima, T., Hiramatsu, N., Enami, M., Zhai, M., and Cong, B., 1993, Coesite bearing granulite retrograded from eclogite in Weihai, eastem China: Europea n J oumal of Mineralogy, 5, 141-152.

Yang, W., 2000, Analysis of deep intra c ontinental subduction: Ep iso des, 23, 20-24.

Yao, Y., Ye, K., Lu, J ., Cong, B., and Wang, Q., 2000, A transitional ec logite- to high pressure granulite-facies overprint on coesite-ec logite at Ta ohang in the Sulu ultra high-pressure terrane, ea stem China: Lithos,, 52, 109-120.

Yin, A., and Nie, S., 1993, An indentation model for the north and south China collision and the development of the Tan-Lu and Honam fault systems, eastem China: Tectonic s, 12, 801-813.

Zhai, M., Cong, B., Guo, J., Luu, W., Li, Y., and Wang, Q., 2000, Sm-Nd geochronology and petrography of gamet pyroxene granulites in the northem Sulu region of China and their geotectonic interpretation: Lithos, 52, 23-33. 
Zhang, R.Y., Liou, J.G., and Cong, B., 1994, Petrogenesis of gamet-bearing ultramafic rocks and associated eclogites in the Su-Lu ultrahigh-pressure metamorphic terrane, eastem China: J oumal of Metamorphic Geology, 12, 169-186.

Zhang, R.Y., Hirajima, T., Banno, S., Cong, B., a nd Liou, J .G., 1995, Petrology of ultra high-pressure rocks from the so uthem Su-Lu region, eastem China: J oumal of Metamorphic Geology, 13, 659-675. 


\section{RGURES}

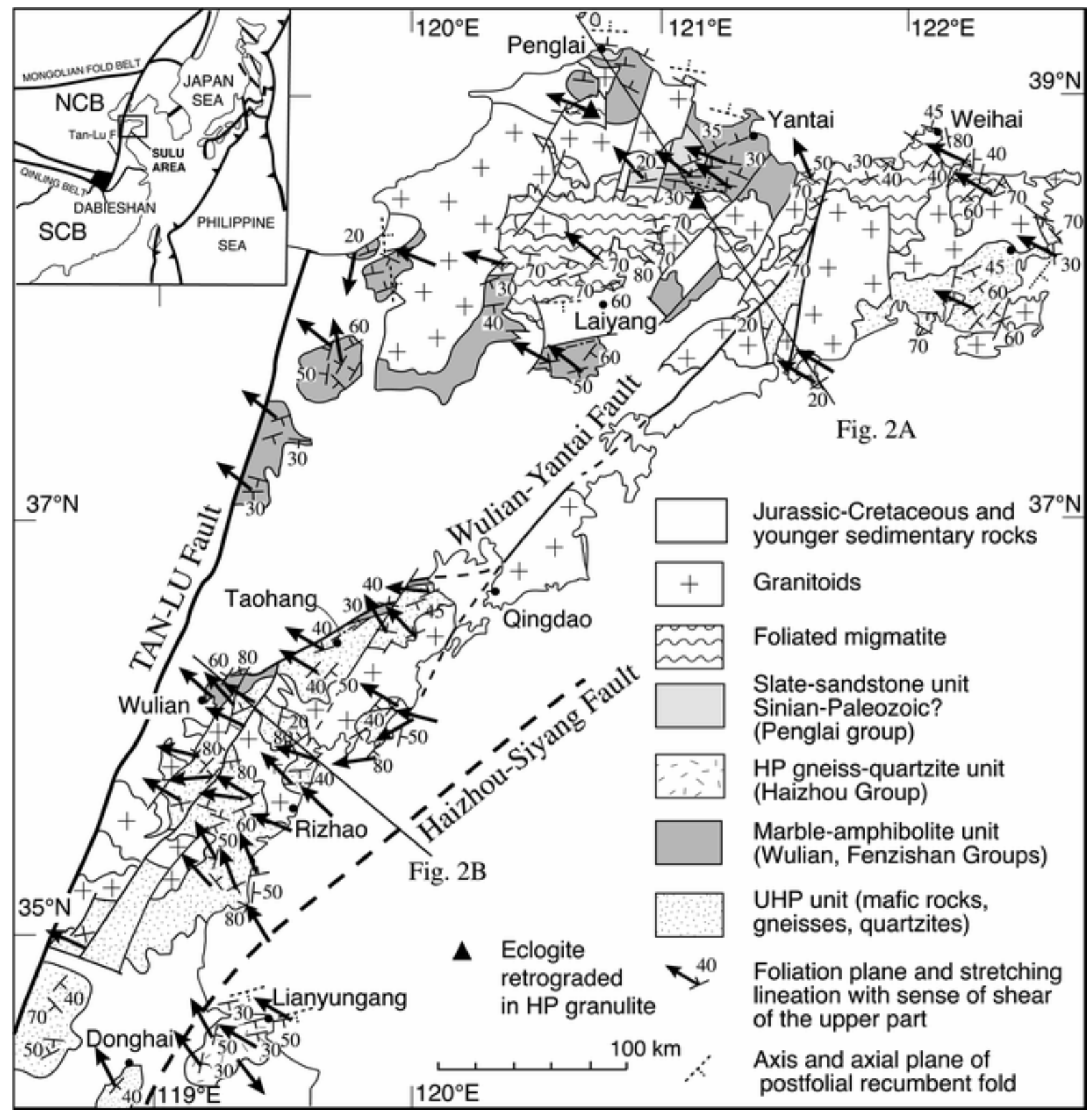

Figure 1. Structural and kinematic map of Sulu area. Lineation arrows point toward sense of shear of upper part. HP-high pressure; UHP-ultrahigh pressure; NCB_North China block; SCB_-South China block 

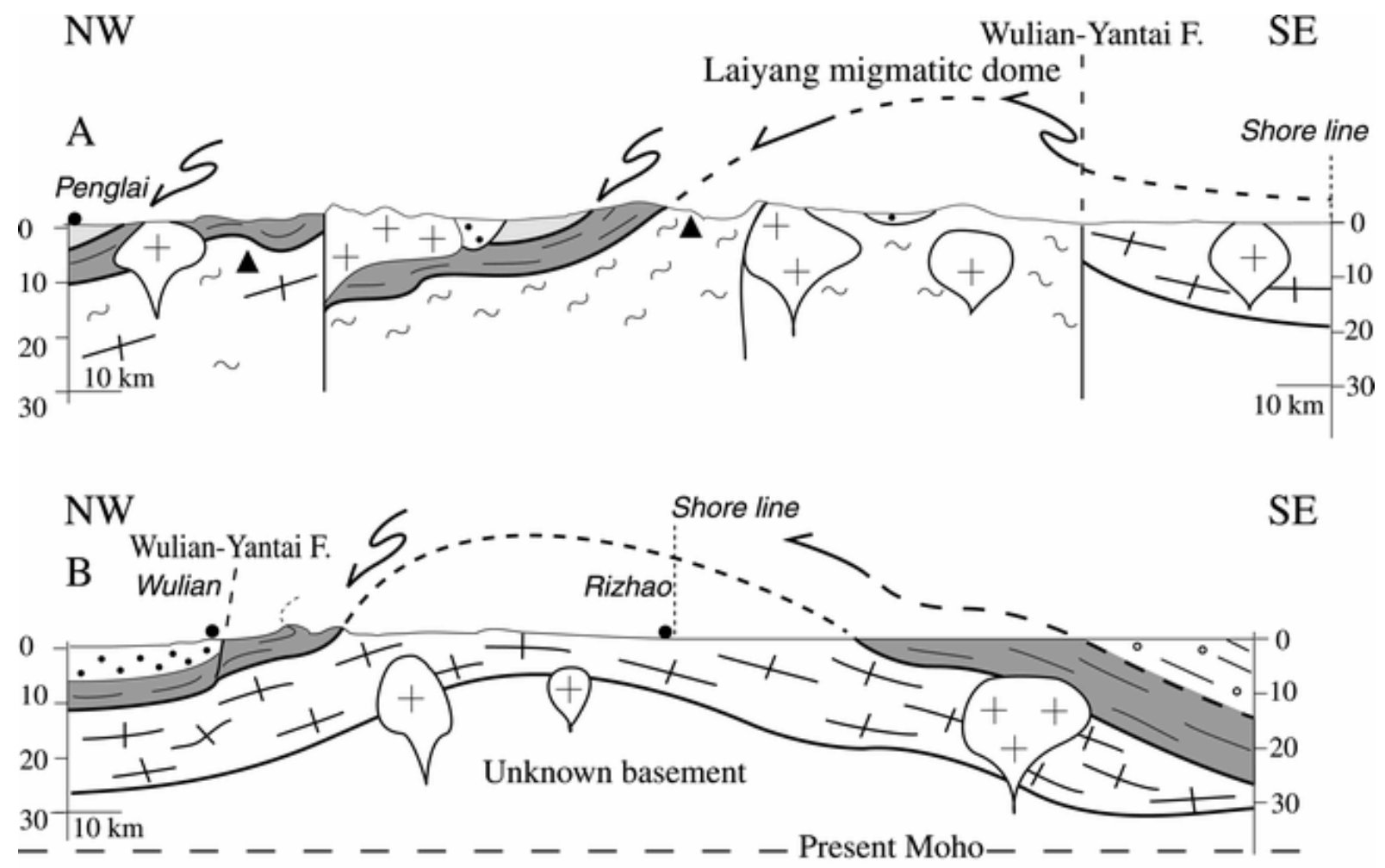

$\because$ Jurassic-Cretaceous and younger sedimentary rocks + Granitoids

$\sim$ Migmatite with retrograded granulite
Slate-sandstone unit Sinian-Paleozoic? (Penglai Group)

Marble-amphibolite unit (Wulian, Fenzishan Groups)
- $\circ$ Gneiss-quartzite (Haizhou Group)

$\times$ UHP unit (mafic rocks, gneisses, quartzites)

Figure 2. Cross sections through Sulu area (located in Fig. 1) showing stack of allochthonous units. By analogy with Dabieshan, geometry of ultrahighpressure (UHP) unit is considered as few-kilometers-thick slab underlain by gneiss free of UHP assemblages. $\mathrm{F}$ is fault 


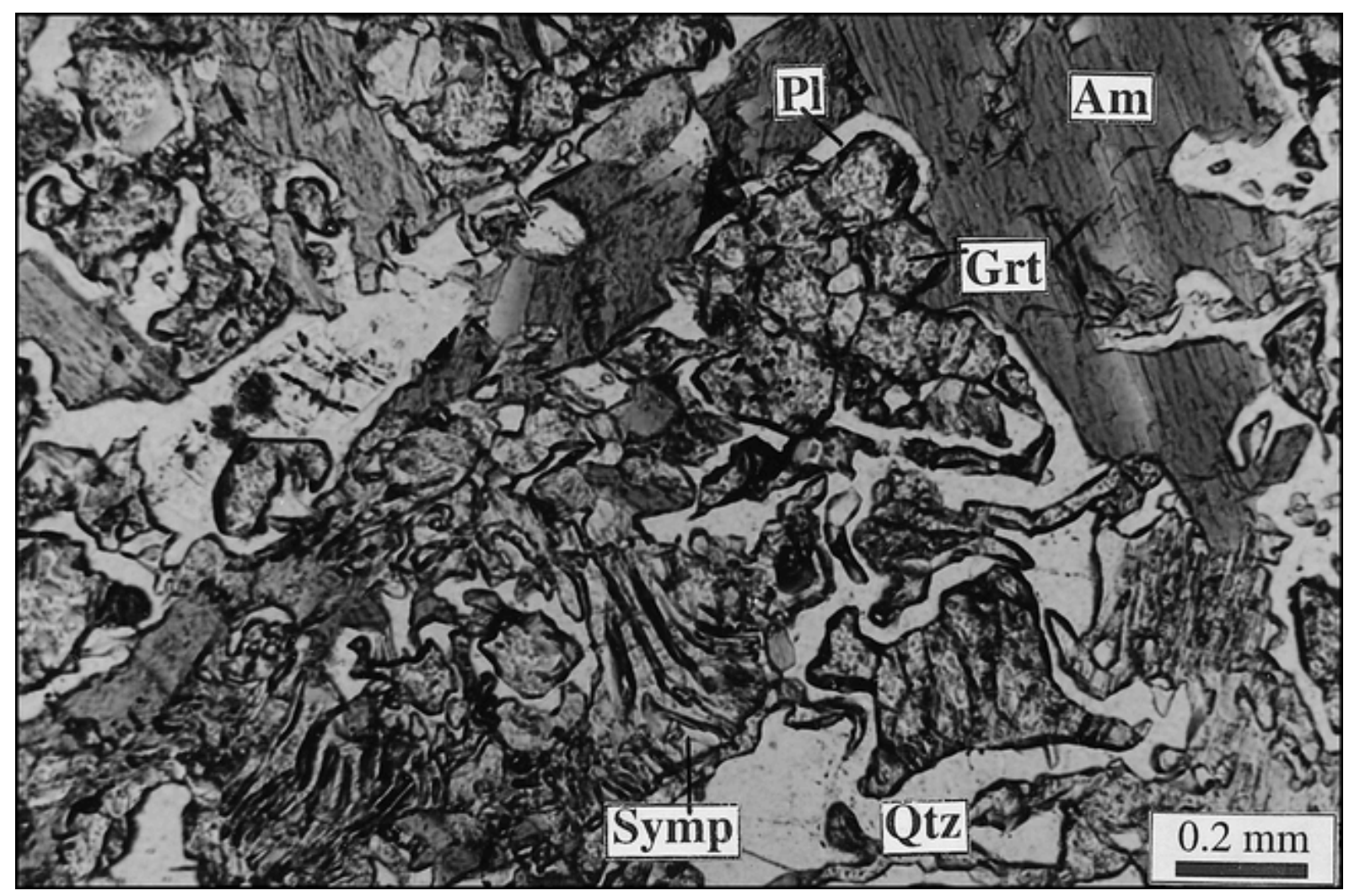

Figure 3. Symplectitic texture of high-pressure granulite formed by retrograde metamorphism of eclogite (south of Penglai, location in Fig. 1). Grt, Pl, Am, Symp, and Qtz are gamet, plagioclase, amphibole, symplectite, and quartz, respectively. 


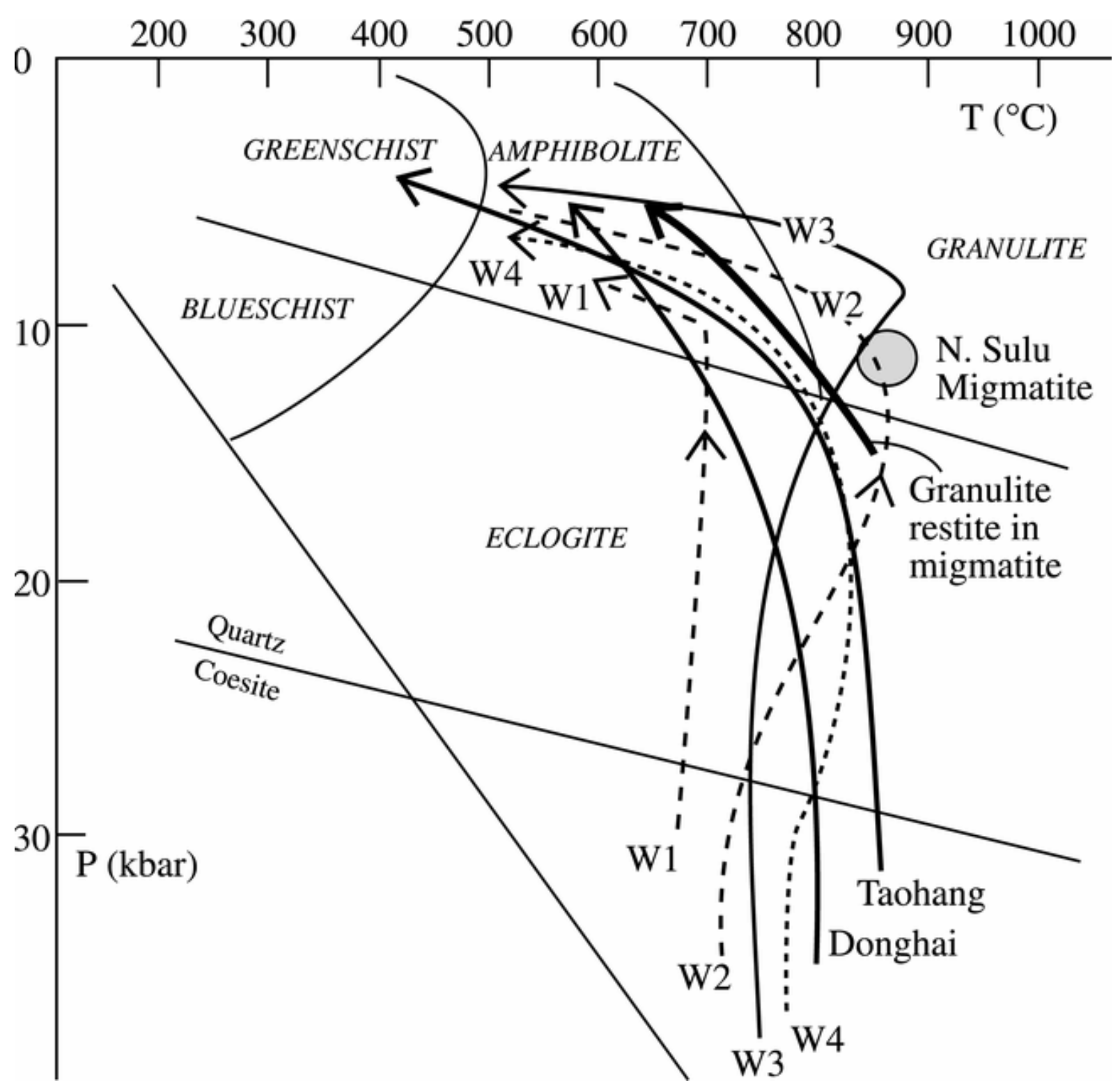

Figure 4. Contrasted pressure-temperature (P-T) paths inferred from different tectonometamorphic units, namely, nonmigmatized ultrahigh-P unit: Donghai (Zhang et al., 1995 ); Taohang (Yao et al., 2000 ); granulitized eclogite in Weiha i, W1 (Banno et al., 2000 ), W2 (Wang et al., 1993), W3 (Zhai et al., 2000 ), W4 (Zूang et al., 1995); granulite restite in migmatite (Zhai et al., 2000 ). Gray circle corresponds to P-T field of migmatite north of Laiyang (Enami et al., 1993 ). Note that P-T path of granulite facies restite does not differ from that of gra nulitized eclogites 


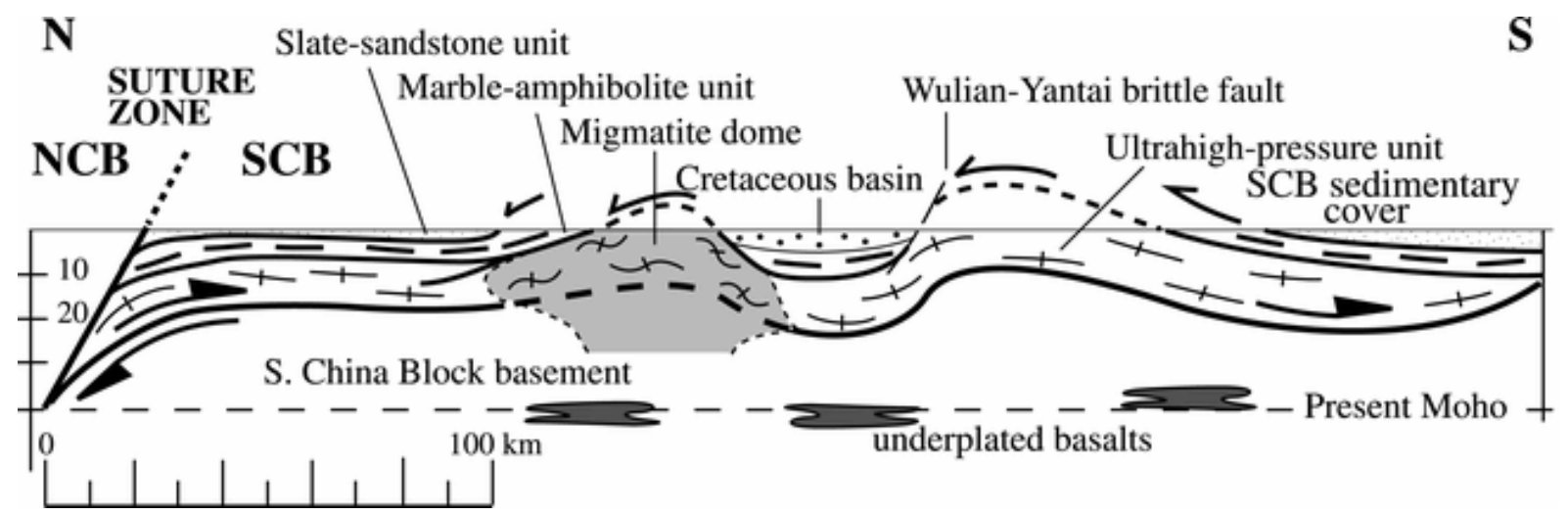

Figure 5. Crustal-scale cross section of Jiaodong peninsula. Suture zone between North China block (NCB) and South China block (SCB) is placed north of migmatitic dome of north J ia odong. Deep structure of SCB is inferred from seismic data (Yang, 2000). Cretaceous plutons have been omitted for clarity 